УДК 159.942.53

О. О. АБРАМЮК, А. С. ЛИПЕЦЬКА

\title{
КОНЦЕПТУАЛЬНА СТРУКТУРА ФЕНОМЕНУ «СУБ'ЄКТИВНЕ БЛАГОПОЛУЧЧЯ» ТА ОСОБЛИВОСТІ ЙОГО ВИМІРЮВАННЯ
}

У статті розглянуто та структуровано існуючі підходи до поняття благополуччя. Вирізнено та обтрунтовано феномен суб'єктивного благополуччя з поміж ряду інших подібних за змістом концептів, виділено його основні структурні компоненти. Здійснено аналіз існуючих підходів емпіричного вивчення благополуччя, наголомено на відсутності універсальної методики дослідження суб'єктивного благополуччя та доиільності поєднання існуючого інструментарію діагностики для врахування всього спектру чинників, щзо впливають на переживання суб' єктивного благополуччя особистістю.

Ключові слова: благополуччя, щастя, суб'єктивне благополуччя, психологічне благополуччя, компоненти суб'єктивного благополуччя, якість життя.

B статье рассмотрены и структурированы существующие подходы $\kappa$ понятию благополучия. Выделено и обоснованно феномен субъективного благополучия из числа других подобных по содержанию концептов, выделены его основные структурные компоненты. Осуществлен анализ существующих подходов эмпирического изучения благополучия, отмечено отсутствие универсальной методики исследования субъективного благополучия и целесообразность сочетания существующего инструментария диагностики для учета всего спектра факторов, влияющих на переживания субъективного благополучия личностью. 
Ключевые слова: благополучие, счастье, субъективное благополучие, психологическое благополучие, компоненты субъективного благополучия, качество жизни.

Постановка проблеми та актуальність дослідження. Поняття суб'єктивне благополуччя має міждисциплінарний характер та розглядається у низці суспільних та природничих наук, оскільки благополуччя окремої людини безсумнівно впливає на благополуччя населення країни та $є$ важливим вектором соціально-економічної політики демократичної держави. 3 однієї сторони це пояснює той факт, що наукові дослідження цього феномену загалом сфокусовані на економічному аспекті, а 3 іншої - нерозв'язаною досі залишається проблема визначення психологічної картини суб'єктивного благополуччя, механізмів його формування та способів досягнення. Науковий інтерес до цього явища обумовлений низкою об'єктивних обставин, оскільки сьогодення ставить нові виклики перед сучасною особистістю, диктує їй незнані досі умови існування та надшвидкісні зміни цих умов. Для суспільства, що вишукує нові шляхи свого розвитку, формує цінності та ідеали, надзвичайно важливим стає віднайти ресурси для сучасної людини, простір для можливості ії самоактуалізації та способи, що дозволять покращити іï якість життя та емоційний комфорт. Так, в рамках позитивної психології на зламі XX-XXI ст. центральним вектором наукових пошуків стає феномен благополуччя, що покликаний знайти відповідь на запитання «Що і як робить людину щасливою?». Незважаючи на широку представленість проблематики суб'єктивного благополуччя (SWB (subjective well-being)) у літературі, в наукових колах сьогодні немає чіткої узгодженості щодо цього поняття. У зарубіжних виданнях йде жвава полеміка щодо розуміння самого явища суб'єктивне благополуччя та диференціації поняття 3 поміж ряду йому близьких. Нерозробленим залишається питання розмежування і виокремлення провідних компонентів суб'єктивного благополуччя та способів їхньої діагностики. Саме тому актуальним є узагальнення існуючих поглядів щодо розуміння суб'єктивного благополуччя та способів його емпіричного вивчення. Звідси, мета статті - теоретикометодологічний аналіз феномену суб'єктивного благополуччя особистості, кристалізація дефініції з поміж ряду інших подібних за змістом понять, а також виділення основних структурних компонентів цього феномена та способів їх операціоналізації.

Аналіз останніх досліджень і публікацій. Феномен благополуччя в сучасній психологічній науці досліджували Н. Бредбурн, Е. Дінер, М. Ягода, К. Ріфф, М. Селігман, М. Аргайл, В. Вілсон, А. Вотерман, Р. Раян, Е. Десі, Д. Канеман, А. Вороніна, І. Джидар'ян, Р. Шаміонов, Л. Куликов, Н. Фетіскін, О. Ширяєва, Т. Шевеленкова, П. Фесенко, та ін. Проблематика позитивного функціонування особистості розглядається в поняттях: емоційний баланс (Н. Бредбурн [9]), щастя (С. Любомирські, І. Джидарьян [2]), психологічне благополуччя (К. Ріфф [11], Д. Канеман [14]), якість життя (Вентегодт [15], задоволеність життям (Е. Дінер [10]), благополуччя (Н. Шварц, Р. Раян, Е. Десі [13]). Е. Дінер [10], І. Джидар'ян [2], Л. Куликов [4] визначили сутність поняття суб'єктивного благополуччя, Е. Діннер [10], К. Ріфф [12], Т. Шевеленкова та П. Фесенко [7] запропонували модель формування благополуччя особистості, Д. Леонтьєв, Р. Шаміонов [6] виявили зв'язок з ціннісносмисловими утвореннями. У найсучасніших дослідженнях Р. Еммонс акцентує увагу на виявленні впливу життєвих цілей на суб'єктивне благополуччя, А. Кампбелл, Ф. Конверс - на якості життя в соціально-психологічному аспекті, М. Аргайл, Е. Діннер - на наповненні новим змістом поняття суб'єктивного благополуччя, А. Вотерман - експериментальному виявленню відмінностей між гедоністичним та евдемоністичним підходами до розуміння благополуччя [14; 16]. Необхідно відмітити, що $з$ кожним роком наукове знання про поняття благополуччя змінюється: уточняються його компоненти, досліджуються детермінанти на макро- та мікрорівнях, а також встановлюються фактори, що чинять вплив на суб'єктивне благополуччя особистості.

Вітчизняна психологія до цієї проблематики звернулась на межі XX-XXI ст. Теоретичні розробки здійснювалися щодо емоційного ставлення до свого життя, що $є$ одним 3 провідних компонентів суб'єктивного благополуччя. Серед українських науковців, які нині досліджують цю проблематику, потрібно назвати В. Духневича, Л. Сохань, Т. Титаренко і ін.

Мета дослідження полягає у теоретичному аналізі феномену «суб'єктивне благополуччя» та способів його діагностики.

Виклад основного матеріалу дослідження. Вивчення проблематики суб'єктивного благополуччя корінням сягає в античну філософію. Історично-філософський аналіз поняття свідчить, що воно починає свій шлях задовго до нашої ери і бере початок у конструкті “щастя” в якості міри суб'єктивного благополуччя. Феномен «щастя» належить значною мірою екзистенціальному аспектові буття особистості, сприйняттю і розумінню світу людини i природи загалом. У багатовіковій історії можна виділити дихотомічне («об'єктивне - суб'єктивне») розуміння щастя. Протягом тривалого періоду античності його розцінювали як здатність, можливість людини володіти

Випуск 11, 2018. Збірник наукових праць РДГУ 
найвищими чеснотами і благами. Пізніше, в ранньохристиянських вченнях, поступово формується суб'єктивне розуміння щастя, тобто почуття щастя не залежить від зовнішніх факторів. У такій двоїстій природі феномену щастя полягає його двояка обумовленість - об'єктивна, пов'язана 3 умовами і обставинами життя людини, і суб'єктивна, що пов'язана 3 внутрішнім світом людини і обумовлює його сприйняття життя, ставлення до неї. Новий час наповнив поняття більш натуралістичними відтінками і досліджуване поняття звелося до поняття “задоволення". До другої половини XX ст. поняття «благополуччя» досліджувалося в контексті аналізу таких концептів, як “щастя” (Happiness), «задоволеність життям» (Life Satisfaction), «якість життя» (Quality of Life).

У світовій психологічній науці сформувалися два основних підходи до розуміння природи благополуччя: гедоністичний і евдемоністичний. Обидва напрямки зароджуються у філософському контексті i корінням сягають в Античність. В межах гедоністичного напрямку поняття «благополуччя» синонімізується з конструктом «задоволення" (від епікурейського поняття hedonia). Найвищі блага розглядалися прихильниками гедонізму як сукупність фізичних задоволень, розмаїтих тілесних чуттєвих насолод різної інтенсивності та тривалості (Аристіп 3 Кирени та його послідовники). На противагу гедоністичному напрямку в розумінні щастя, в філософії Античності постає евдемоністичний, основоположником якого вважають Арістотеля. Евдемонізм постав на фундаменті ідеї внутрішньої свободи Сократа, що досягається завдяки самосвідомості особи та їі незалежності від зовнішнього світу. Арістотель заперечує задоволення як першопричину щастя, він називає «гедонічне щастя - вульгарним ідеалом», стверджуючи, що такий підхід робить людей рабами власних бажань [1]. Щастя, за Арістотелем, це подолання прагнення до відчуттів та насолод шляхом самообмеження, самодисципліни, звільнення від прив'язаностей до зовнішнього світу та його благ, а свобода, що досягається при цьому від зовнішньої необхідності та мінливості долі, то розумність, тотожна справжній чесноті.

У психології гедоністичний підхід до розуміння понять «щастя» та «благополуччя» розширило своє трактування в рамках біхевіоризму, психоаналізу до переживання задоволення на противагу дискомфорту (незадоволення) з позиції уявлень людини про добре і погане в іiі житті. Теоретичну базу досліджень феномена «благополуччя» в зарубіжній психології заклали Н. Бредберн у 60-ті pp. 20 ст. та його послідовник Е. Дінер, опираючись саме на ідеї гедонізму. Серед перших праць, що присвячені змістовному обгрунтуванню поняття «благополуччя» потрібно виділити публікації «Структура психологічного благополуччя» Н. Бредберна та «Модель людських тривог» $\mathrm{X}$. Кентріла, які грунтувалися на результатах досліджень Національного центру вивчення громадської думки (NORC). Н. Бредберн описував благополуччя в термінах, що описують стан щастя або нещастя, почуття суб'єктивної загальної задоволеності або незадоволеності життям загалом. Науковцем також було показано, що позитивний і негативний афект - це не два полюси однієї шкали і вони мають різну природу. Відповідно, благополуччя, за визначенням Н. Бредбурна, - це баланс, який досягається постійною взаємодією двох видів афекту - позитивного і негативного, що виявляється у вигляді загального відчуття задоволеності або незадоволеності життям [9]. Термін «суб'єктивне благополуччя» увів американський психолог Е. Дінер, який розглядає трикомпонентну структуру суб'єктивного благополуччя до складу якої входять наступні компоненти: задоволення, приємні емоції та неприємні емоції. На думку Е. Дінера, суб'єктивне благополуччя включає в себе когнітивну оцінку різних сторін життя і емоційне самоприйняття, а переживання суб'єктивного благополуччя можна порівняти 3 переживанням щастя [10]. Такі оцінки носять суб'єктивний характер, оскільки вони мають великий інтернальний досвід, тобто це не є оцінки будь-якого зовнішнього явища; вони представляють собою аспекти благополуччя у частині відношення до приємності і бажаності чи протилежних конкретних станів і аспектів життя людей.

Ідеї евдемонізму в 20 ст. розроблялись представниками гуманістичної психології, що описують різні аспекти позитивного функціонування особистості, оперуючи при цьому терміном психологічного благополуччя. Стрижневою ідеєю евдемоністичного підходу є уявлення про сенс життя, самореалізація, а благополуччя $є$ можливим наслідком осмисленого та наповненого повноцінного буття. Е. Фромм [7], спираючись на арістотелівський погляд стверджував, що оптимальне благополуччя (vivere bene) вимагає розмежування між тими потребами (бажаннями), які суб'єктивно відчуває людина і втамування яких призводить до миттєвого задоволення, та тих потреб, які кореняться у людській природі, реалізація яких сприяє людському росту та викликає «евдемонію», тобто відчуття благополуччя. Серед авторів, що займалися теоретичною розробкою векторних питань психологічного благополуччя - Дж. Бюдженталь, А. Маслоу, К. Роджерс, Е. Фромм, Г. Олпорт, К. Юнг, Е. Еріксон. 3 позиції даного підходу благополуччя розглядають як “повноту самореалізації людини в конкретних життєвих умовах і обставинах, знаходження «творчого синтезу між відповідністю запитам соціального оточення і розвитком власної індивідуальності» [5, 
c. 112]. 3 погляду представників евдемоністичного підходу, психологічне благополуччя презентує перш за все здатність людини реалізовувати власну індивідуальність, ставати і бути суб'єктом, творцем власного життя через включення в певну соціальну діяльність, виконання тих чи інших соціальних ролей. В рамках евдемоністичного підходу на основі більш ранніх досліджень М. Ягоди, К. Ріфф розробила власну багатомірну модель психологічного благополуччя, у якій виділила шість складових [12, с. 720-724]: самоприйняття - людина усвідомлює і приймає різні сторони своєї особистості; позитивні стосунки 3 оточуючими - вміння співпереживати, бути відкритим для спілкування, а також наявність навичок, що допомагають встановлювати і підтримувати контакти 3 іншими людьми, бажання бути гнучким у взаємодії з соціумом, вміння прийти до компромісу; автономність - здатність мислити і діяти незалежно від тиску соціуму; управління довкіллям здатність створювати сприятливі умови для реалізації своїх цінностей, цілей і потреб; ціль підтримує почуття осмислення власного теперішнього, минулого і майбутнього; особистісний ріст почуття подальшого зростання і розвитку людини як особистості. На основі перелічених складових авторка розробила методику дослідження психологічного благополуччя. К. Ріфф в апріорі вважає людину психологічно благополучною, якщо вона «повноцінно функціонує» і $є$ «зрілою» особистістю, хоча варто відмітити, що це не означає, що вона цим задоволена, отримує насолоду від життя чи в неї позитивні емоції явно переважають кількісно та якісно негативні переживання, тобто, що вона насправді благополучна. Утакому ракурсі зрозумілим $\epsilon$ те, що ціннісний аспект буття людини може бути лише складовою благополуччя і не відображає суб’єктності її позиції.

Досі йде жвава полеміка у наукових колах щодо співвіднесеності понять суб'єктивного та психологічного благополуччя. Так, К. Ріфф, Е. Дінер, вважають, що суб'єктивне благополуччя $є$ складовою психологічного благополуччя, Н. Бахарєва, Л. Куликов, М. Соколова, Р. Шаміонов і ряд інших авторів вважають, що, навпаки, психологічне благополуччя є частиною суб'єктивного. В окремих дослідженнях та публікаціях можна зустріти трактування цих понять як синонімічних (Н. Бредбурн, Е. Паніна, Е. Бочарова та ін). Таку ж думку висловлюють і П. Фесенко та Т. Шевеленкова, трактуючи феномен психологічного благополуччя як суб'єктивне явище, цілісне переживання, виражене в суб'єктивному відчутті щастя, задоволеності собою і власним життям, а також пов'язуючи його з базовими людськими цінностями і потребами та позитивним функціонуванням особистості [6, с.95-96]. Трактування поняття “благополуччя" тим не менше значною мірою схожі або збігаються в різних наукових дисциплінах і буденній свідомості. Благополуччя і почуття благополуччя дуже значимі для всього суб'єктивного світу особистості.

За останні роки з'явилася тенденція об'єднувати гедоністичний та евдемоністичний погляди на проблему благополуччя (Р. Бісвас-Е.Дінер, Т. Кашден, Л. Кінг [8], Р. Райан, Е. Дісі [13], Т. Д. Шевеленкова, П. П. Фесенко [6] та ін.). Зокрема, Р. Бісвас-Е.Дінер, Т. Кашден, Л. Кінг пропонують монолітний підхід до вивчення та опису поняття «благополуччя», оскільки вважають, «що евдемоністичні та гедоністичні аспекти благополуччя можуть працювати в тандемі. Зосередження уваги на дослідженні конкретних аспектів благополуччя, а не на проведенні різниці між двома розуміннями благополуччя, сприяє більш ефективному дослідженню проблеми» [8; с. 208]. 3 позиції даного підходу суб'єктивне психологічне благополуччя виступає як показник ступеня спрямованості на реалізацію основних компонентів позитивного функціонування та ступеня реалізованості даної спрямованості, яка суб'єктивно виражається у домінуванні позитивного афекту, задоволеності собою та життям. Так, не випадково тут ми вжили поєднання термінів суб'єктивного і психологічного благополуччя, оскільки вбачаємо доцільним інтегрувати описані вище підходи, що є, на нашу думку, не взаємовиключними, а навпаки - взаємодоповнюваними, для утворення єдиної концепції, яка синтезує і не заперечує досвід та наукові здобутки обох підходів. Таке цілісне утворення і складатиме суб'єктивне відображення психологічної реальності особистості. А введення в науковий обіг єдиного інтегрованого поняття дозволить уникнути плутанини у вживанні, розумінні та діагностиці феномену суб'єктивне психологічне благополуччя.

У рамках Організації економічного співробітництва та розвитку (OECD) досягнуто консенсусу серед експертів різних галузей, в тому числі психології, щодо вживання терміну «суб'єктивне благополуччя», однак його сутність виходить за межі визначення Е. Дінера [14]. Тому визначення чіткої концептуальної структури для суб'єктивного благополуччя $є$ теоретичною та практичною необхідністю, що уможливлює окреслення меж поняття та вимірювання його найбільш точно та коректно. Першим етапом концептуальної структури вимірювання суб'єктивного благополуччя буде визначити, що описує поняття. Як засвідчує аналіз основних концепцій благополуччя, існує потенційно широкий спектр суб'єктивних явищ, про які люди могли б повідомляти, не всі з яких відображатимуть сутність «суб'єктивного благополуччя» Суб'єктивне благополуччя $є$ свого роду внутрішнім мірилом, критерієм і регулятором буття суб'єкта, в якому

Випуск 11, 2018. Збірник наукових праць РДГУ 
сходяться його життєві цілі, програми і їх реалізація. Оскільки людина - істота соціальна, що володіє особистісністю, іiі цілі і сценарії життя забезпечені всією історією існування людства і взаємодією 3 іншими в мікро- і макросоціумі в репрезентованому їй вигляді. Будучи суб'єктом соціального буття, особистість здатна інтегрувати безліч власних проявів і об'єктивних обставин своєї життєдіяльності. При цьому, незважаючи на певні відмінності емоційно-оцінного ставлення до реалізації себе в різних буттєвих просторах, $\epsilon$ інваріантні складові, забезпечені ефектами соціалізації. Вивчення суб'єктивного благополуччя особистості ускладнюється 3 огляду на поєднання змінних - досить стійкою стратегією оцінки і власне буттєвих стосунків, забезпечених суб'єктною позицією, суб'єктними властивостями, рефлексивними механізмами тощо. Існують певні труднощі у співвіднесенні буттєвих просторів, які не можуть бути визнані рівнозначними для суб'єкта і в різній мірі визначають психологічну картину суб'єктивного благополуччя. Крім того, цілісне переживання життя і дискретні оцінки різних явищ життя можуть в значній мірі розходитися. Як відомо, здатність людини ініціювати свою активність, визначаючи і розширюючи буттєві простори, $є$ найважливішою властивістю суб'єкта. У той же час вибудовування життєдіяльності та соціальних і соціальнопсихологічних стосунків вимагає зосередження на цільових, процесуальних i результуючих характеристиках активності, iii регуляції (саморегуляції). Насправді емоційно-оцінне ставлення до своєї активності, взаємин, себе (самореалізації) і загалом до життя є, з одного боку, індикатором ії успішності, а 3 іншого, виступає іiі своєрідним “збудником”, активатором. Отже, суб'єктивне благополуччя - це інтегральне динамічне утворення; воно не передбачає одночасності позитивних векторів у всіх сферах активності, характеризується діахронією різних складових, але при цьому утворюється за рахунок певного критичного накопичення і рефлексії досвіду.

Існує місце для полеміки про те, які саме компоненти повинні бути включені у термін «суб'єктивне благополуччя». Зокрема, відмінність зазвичай робиться між оцінками життя, які включають когнітивну оцінку життя респондента загалом (або їі аспектів), а також виміри афекту, що охоплюють почуття, які переживає респондент в конкретний момент часу (Дінер, Канеман і Крюгер). У доповненні до різниці між оцінкою і афектом, ряд дослідників стверджують, що існує також явно евдемоністичний аспект суб'єктивного благополуччя, що відображає почуття людиною мети i залученості (Хюперт і ін.) [14]. Так, спираючись на цілісний підхід до вивчення суб'єктивного благополуччя та ідею інтегрального підходу до його операціоналізації, концептуальної структурою, що слугує фундаментом при вимірюванні суб'єктивного благополуччя буде: оцінка життя когнітивна сфера; афект - емоційна сфера; евдемонія - ціннісно-мотиваційна сфера.

Вимірювання суб'єктивного благополуччя є складною діагностичною проблемою, яка лежить в площині міждисциплінарних теоретичних та практичних розробок, саме тому перед науковцями нерідко постає необхідність вибору адекватного психодіагностичного інструментарію. Внаслідок детального аналізу зарубіжних та вітчизняних публікацій, що присвячені методологічним питанням вимірювання суб'єктивного благополуччя, варто констатувати, що сьогодні немає розробленої універсальної методики, яка б охоплювала усі три сфери суб'єктивного благополуччя, що спонукало здійснити вибірку методик, що визначають описані вище аспекти, оскільки вбачаємо повним та діагностично вірним використання інтегрального підходу до існуючих концепцій і врахування всього спектру об'єктивних та суб'єктивних факторів ( див. табл. 1).

Таблиця 1.

Емпіричне дослідження компонентів суб'сктивного благополуччя

\begin{tabular}{|l|l|l|l|}
\hline Феномен & $\begin{array}{l}\text { Досліджуваний } \\
\text { аспект }\end{array}$ & \multicolumn{1}{|c|}{ Дескриптор } & \multicolumn{1}{|c|}{ Методики } \\
\hline \multirow{3}{*}{} & $\begin{array}{l}\text { когнітивний } \\
\text { компонент }\end{array}$ & загальна задоволеність життям; & $\begin{array}{l}\text { Шкала задоволеності життям (авт. } \\
\text { Е. Дінер) }\end{array}$ \\
\cline { 2 - 4 } & $\begin{array}{l}\text { афективний } \\
\text { компонент }\end{array}$ & $\begin{array}{l}\text { інтенсивність позитивних } \\
\text { переживань загалом; } \\
\text { оцінку індивідом власного } \\
\text { емоційного стану }\end{array}$ & $\begin{array}{l}\text { Оновлений } \\
\text { опитувальник щастя, (авт. М. Аргайл) } \\
\text { Шкала суб'єктивного благополучяя } \\
\text { (авт. А. Перуе-Баду та ін.) }\end{array}$ \\
\cline { 2 - 4 } & $\begin{array}{l}\text { самоприйнятя; } \\
\text { взаємовідносини з оточенням; } \\
\text { жотиваційний } \\
\text { компонент }\end{array}$ & $\begin{array}{l}\text { Шкала психологічного благополуччя } \\
\text { (авт. К. Ріфф) }\end{array}$ \\
\hline
\end{tabular}

Як видно з таблиці, когнітивна компонента феномену визначається за допомогою «Шкали задоволеності життям «(Satisfaction with Life Scale (SWLS), Diener, 1993 р.), що найбільш точно відображає суб'єктивну оцінку особистістю власного життя. Емоційна складова досліджується за допомогою Оновленого Оксфордського опитувальника щастя (Oxford Happiness Inventory (OHI), 
М. Аргайл), який вимірює інтенсивність позитивних переживань загалом, та «Шкали суб’єктивного благополуччя» (Échelle pour l'évaluation subjective du Bien-être, А. Перуе-Баду та ін.), яка відображає оцінку індивідом власного емоційного стану - оцінює якість емоційних переживань людини в діапазоні від оптимізму, бадьорості і впевненості в собі до пригніченості, дратівливості і відчуття самотності. Ціннісно-мотиваційна складова суб'єктивного благополуччя визначається за допомогою Методики «Шкала психологічного благополуччя» (авт. К. Ріфф) і відображає позитивне психологічне функціонування людини та те, наскільки ії діяльність конгруентна стійким цінностям особистості.

Такий діагностичний інструментарій відображає складність та поліфонічність феномену суб'єктивне благополуччя та є, на нашу думку, вичерпним для висвітлення багатоаспектної природи цього феномену.

Висновки 3 даного дослідження та перспективи подальших розвідок. Вивчення проблематики суб'єктивного благополуччя корінням сягає в античну філософію, де розглядається в термінах «щастя» $\mathrm{i}$ «блага». Поняття «благополуччя» має міждисциплінарний характер, кристалізується дефініція у другій половині XX ст. у рамках позитивної психології та виходить за межі медичної моделі «благополуччя - неблагополуччя» під впливом екзистенційних теорій. Переживання суб'єктивного благополуччя є однією з провідних умов повноцінного функціонування особистості в суспільстві, умовою та наслідком її як самоактуалізації, так і адаптації до оточуючого середовища. Дослідження проводилося в межах окремих шкіл та напрямів, в першу чергу гедоністичного та евдемоністичного підходів. Гедоністична точка зору зосереджена на суб'єктивному благополуччя, яке визначається як стале превалювання у людини позитивних емоцій та переживань над негативним, обумовлюється мірою задоволеності життям та його аспектами i носить суб'єктивний характер. На противагу цьому, евдемоністична точка зору зосереджується на психологічному благополуччі, що є одним із проявів позитивного функціонування особистості, детерміноване особливостями особистісного росту людини та наявністю мети у житті. Грунтовний аналіз філософського коріння сформованих підходів до проблематики благополуччя дозволив виявити конгруентність бачення обох підходів до проблематики позитивного функціонування особистості та іï задоволеності життям, і разом з тим прослідковується тенденція ставити різні запитання в рамках кожного з зазначених підходів і, звідси, отримувати різні відповіді, що проте доповнюють один одного, а не заперечують, описуючи суб'єктивну психологічну картину особистості в різних контекстах.

Як інтегральне динамічне утворення, суб'єктивне благополуччя не передбачає одночасності позитивних векторів у всіх сферах активності, характеризуючись діахронією різних складових. Концептуальну структуру суб'єктивного благополуччя утворюють емоційний, когнітивний та «евдемоністичний» компоненти. Під когнітивним компонентом розуміємо оцінку індивідом власного життя та задоволеність життям, як основний показник; під емоційним - інтенсивність позитивних переживань загалом та оцінку індивідом власного емоційного стану; під «евдемоністичним» розуміємо функціональні компоненти, що забезпечують оптимальне позитивне функціонування особистості: автономію, управління навколишнім середовищем, особистісне зростання, позитивні відносини з оточуючими, наявність життєвих цілей і самоприйняття.

Представлено комплекс методик, що складають повну і вичерпну добірку діагностичного інструментарію суб'єктивного благополуччя, що спрямований на охоплення всіх його компонентів як цілісного суб'єктивного переживання, основою якого є суб'єктність оцінки та ставлення до власного життя, а також рефлексивна позиція особистості та реалізація ії життєвих цілей.

\section{Список використаних джерел}

1. Арістотель Нікомахова етика / Арістотель ; [пер. 3 старогрец. В. Ставнюка]. - Київ : Аквілон-Плюс, 2002. - 480 с.

2. Джидарьян И. А. Счастье в представлениях обыденного сознания / И. А. Джидарьян // Психологический журнал. - 2000. - Т. 21, № 2. - С. 40-48.

3. Куликов Л. В. Детерминанты удовлетворенности жизнью / Л. В. Куликов // Общество и политика. - Изд-во С.-Петерб. ун-та, 2000. - С. 476-510.

4. Созонтов А.Е. Гедонистический и эвдемонистический подходы к проблеме психологического благополучия / А. Е. Созонтов // Вопросы психологии. - 2006 . - № 4. - С. 105-114.

5. Шамионов Р. М. Субъективное благополучне и ценностно-смысловые образования личности в профессиональной сфере / Р. М. Шамионов // Известия Саратовского университета. Серия Философия. Психология. Педагогика. - 2006. - Т. 6, вып. 1/2. - С. 104-109.

6. Шевеленкова Т. Д. Психологическое благополучие личности / Т. Д. Шевеленкова, П. П. Фесенко // Психологическая диагностика. - 2005. - № 3. - С. 95-121. 
7. Фромм Е. Бути чи мати? / Е. Фромм ; [пер. 3 нім. : О. Михайлова, А. Буряк]. - Київ : Укр. письменник, 2010. - 222 с.

8. Biswas-Diener R. Two traditions of happiness research, not two distinct types of happiness / R. Biswas-Diener, T. B. Kashdan, L. A. King // The Journal of Positive Psychology. - 2009. - Vol. 4, № 3. P. 208-211.

9. Bradburn Norman M. Asking Questions: The Definitive Guide to Questionnaire Design - For Market Research, Political Polls, and Social and Health Questionnaires, Revised Edition / Norman M. Bradburn . - San Francisco : Jossey-Bass A Wiley Imprint, 2004. - 429 p.

10. Diener E. The science of well-being: the collected works. Series: Social Indicators Research Series / E. Diener. - 2009. - Vol. 37. - 274 p.

11. Ryff C. Know Thyself and Become what You Are: A Eudaimonic Approach to Psychological Well-Being / Carol D. Ryff, Burton H. Singer // Journal of Happiness. - 2008. - № 9. - P. 13-39.

12. Ryff C. The Structure of Psychological Well-Being Revisited / Carol D. Ryff, Corey Lee M. Keyes // Journal of Personality and Social Psychology. - 1995. - Vol. 69, № 4. - P. 719-727.

13. Ryan R. M. On happiness and human potentials: A Review of Research on Hedonic and Eudaimonic Well-Being / R. M. Ryan, E. L. Deci // Annual Reviews Psychol. - 2001. - № 52. - P. 141-166.

14. OECD Guidelines on Measuring Subjective Well-being / Organisation for Economic Cooperation and Development (OECD). - Paris : OECD Publishing, 2013. - 265 p.

15. Ventegodt S. Quality of Life Theory II. Quality of Life as the Realization of Life Potential: A Biological Theory of Human Being / S. Ventegodt, J. Merrick, N. Andersen // The Scientific World Journal. - 2003. - № 3. - P. 1041-1049.

16. Waterman A. S. The Implications of Two Conceptions of Happiness (Hedonic Enjoyment and Eudaimonia) for the Understanding of Intrinsic Motivation / A. S. Waterman, S. J. Schwartz, R. Conti // Journal of Happiness Studies. - Vol. 9, № 1. - P. 41-79.

\section{References}

1. Aristotel Nikomakhova etyka / Aristotel ; [per. z starohrets. V. Stavniuka]. - Kyiv : AkvilonPlius, 2002. $-480 \mathrm{~s}$.

2. Dzhidarian I. A. Schastye v predstavleniyakh obydennogo soznaniya / I. A. Dzhidarian // Psikhologicheskiy zhurnal. - 2000. - T. 21, № 2. - S. 40-48.

3. Fromm E. Buty chy maty? / E. Fromm ; [per. z nim. : O. Mykhailova, A. Buriak]. - Kyiv : Ukr. pysmennyk, 2010. $-222 \mathrm{~s}$.

4. Kulikov L. V. Determinanty udovletvorennosti zhiznyu / L. V. Kulikov // Obshchestvo i politika. - Izd-vo S.-Peterb. un-ta. - 2000. - S. 476-510.

5. Sozontov A. E. Gedonisticheskiy i evdemonisticheskiy podkhody $\mathrm{k}$ probleme psikhologicheskogo blagopoluchiya / A. E. Sozontov // Voprosy psikhologii. - 2006 - - № 4. - S. 105-114.

6. Shamionov R. M. Subyektivnoye blagopoluchne i tsennostno-smyslovyye obrazovaniya lichnosti v professionalnoy sfere / R. M. Shamionov // Izvestiya Saratovskogo universiteta. Seriya Filosofiya. Psikhologiya. Pedagogika. - 2006. - T. 6, vyp. 1/2. - S. 104-109.

7. Shevelenkova T. D. Psikhologicheskoye blagopoluchiye lichnosti / T. D. Shevelenkova, P. P. Fesenko // Psikhologicheskaya diagnostika. - 2005. - № 3. - S. 95-121.

8. Biswas-Diener R. Two traditions of happiness research, not two distinct types of happiness / R. Biswas-Diener, T. B. Kashdan, L. A. King // The Journal of Positive Psychology. - 2009. - Vol. 4, № 3. P. 208-211.

9. Bradburn Norman M. Asking Questions: The Definitive Guide to Questionnaire Design - For Market Research, Political Polls, and Social and Health Questionnaires, Revised Edition / Norman M. Bradburn. - San Francisco : Jossey-Bass A Wiley Imprint, 2004. - 429 p.

10. Diener E. The science of well-being: the collected works. Series: Social Indicators Research Series / E. Diener. - 2009. - Vol. 37. - 274 p.

11. Ryff C. Know Thyself and Become what You Are: A Eudaimonic Approach to Psychological Well-Being / Carol D. Ryff, Burton H. Singer // Journal of Happiness. - 2008. - № 9. - P. 13-39.

12. Ryff C. The Structure of Psychological Well-Being Revisited / Carol D. Ryff, Corey Lee M. Keyes // Journal of Personality and Social Psychology. - 1995. - Vol. 69, № 4. - P. 719-727.

13. Ryan R. M. On happiness and human potentials: A Review of Research on Hedonic and Eudaimonic Well-Being / R. M. Ryan, E. L. Deci // Annual Reviews Psychol. - 2001. - № 52. - P. 141-166.

14. OECD Guidelines on Measuring Subjective Well-being / Organisation for Economic Cooperation and Development (OECD). - Paris : OECD Publishing, 2013. - 265 p. 
15. Ventegodt S. Quality of Life Theory II. Quality of Life as the Realization of Life Potential: A Biological Theory of Human Being / S. Ventegodt, J. Merrick, N. Andersen // The Scientific World Journal. - 2003. - № 3. - P. 1041-1049.

16. Waterman A. S. The Implications of Two Conceptions of Happiness (Hedonic Enjoyment and Eudaimonia) for the Understanding of Intrinsic Motivation / A. S. Waterman, S. J. Schwartz, R. Conti // Journal of Happiness Studies. - Vol. 9, № 1. - P. 41-79.

O.O.Abramjuk, A.S.Lipec'ka Conceptual structure of the phenomenon of «subjective well-being» and peculiarities of its measurement

The article is devoted to the problem of the subjective well-being of a personality. The historical development of the concept is clearly outlined. The article considers and structures existing approaches to the concept of well-being. The phenomenon of subjective well-being among the other concepts similar in content is distinguished and substantiated, its main structural components are highlighted. It has been defined that the conceptual structure of subjective well-being is formed by emotional, cognitive, and "eudemonic" components. The cognitive component includes an individual's assessment of one's own life and life satisfaction as a key indicator; emotional - the intensity of positive emotions in general and an individual's assessment of one's own emotional state; "eudemonic " - functional components that provide the optimal positive functioning of an individual: autonomy, environmental management, personal growth, positive relationships with others, the existence of life goals and self-perception.

An analysis of existing approaches to empirical study of well-being is carried out, it is emphasized in the absence of a universal methodology for the study of subjective well-being and the feasibility of combining the existing diagnostic tools to take into account the entire spectrum of factors influencing the experiences of subjective well-being of a personality. The paper presents the set of techniques, which constitute a complete and exhaustive collection of diagnostic tools of subjective well-being, aimed at covering all its components as a holistic subjective experience, which is based on the subjectivity of assessment and attitude towards one's own life, as well as the reflexive position of an individual and realization of one's life goals.

Key words: well-being, happiness, subjective well-being, psychological well-being, components of subjective well-being, quality of life. 